\title{
Innovation of Risk Mitigation Model for Islamic Equaty-Based Financing in Islamic Microfinance Institutions in Indonesia.
}

\author{
Muhammad Pisol Bin Mat Isa*, Naelati Tubastuvi, Sri Wahyuni, Maran Marimuthu, Ridhuan Tony, Muhammad \\ Zul Aiman Zulkifli \& Siti Hajar
}

Universiti Teknologi PETRONAS, 32610 Seri Iskandar, Perak

\begin{abstract}
Islamic Microfinance institution (MFI) funded either by government or private financial institutions are playing an instrumental role in discharging business fund to the eligible micro entrepreneurs (ME). The potential of micro entrepreneurs to succeed in their business is always becoming a central issue, this is due to the ability to manage the business strategy in a sustainable manner. The fund transacted in micro financing industry is small in term of quantity, therefore it also generates small profit to both parties MFI and ME, it may not be profitable in the eye of financial institution such as bank or Microfinance institution such as Baitul Mal wa Tamwil, moreover the financing risk is always high because some of the financing given without proper risk mitigation could lead into financial failure. The above reasons have influenced most of the MFIs's decision to abstain from providing equity-based financing, where the concept very much suitable and workable to bring out the groups of MEs from poverty list in comparison to debt-based financing. Equity-based financing require bigger commitment and intervention from MFI in business in term of coaching, training and managing cash flow of the business. Islamic equity-based financing is about profit and loss sharing (PLS) financing. Where both parties have to bear financial consequences in the event of business failure. The failure in business would cause non-performing financing (NPF) to the financial institution and could effect the financial position for that particular year of report. The continuous NPF to the MFI can risk the company future plan. Thus, this study aimed to explore the mechanism of risk mitigation for equity-based financing which can be adopted by Islamic microfinance institutions around the would. The mechanism used to suggest in area of governance, selection of entreprenuer, financing arrangement, payment system and business business sectors. The study applied content analysis to collect the history data of equity-based financing as offered by BMT and MFIs in Indonesia, the data informed researcher on the success and failure story, the study also applied structured interview with managers who are responsible on risk mitigation. The study found that BMT and MFIs in Indonesia are well-organized, the governance and selection of entreprenuer are palying significant role while the payment system which includes the collatoral against any negligence posits an effective way in mircofinance mitigation model.
\end{abstract}

\section{Introduction.}

The world bank declared year of 2005 as the microfinance year with the objective to alleviate the world poverty (Abdul Rahim Abdul Rahman, 2007), (husni, 2019) (Abdul Rahman, 2007). Microfinance has been proven to be a successful financing in tackling the world poverty. Microfinance initiative is acclaimed as an approach to bring about development and creating wealth through development of microenterprises. Microfinance institutions provide financial services to poor entrepreneurs through proper scheme tailored suit their business needs and conditions. The scheme will help the poor to increase their household income and economic security (Juwaini \& Mintarti, 2010). The features of microfinance are about disbursement of small size of loan to micro entrepreneur normally there are limited financial means and having difficulty. The fundamental difference between Islamic microfinance and conventional microfinance are on the concept of financing and products, Islamic financing offers both equity and debt financing, the financing fund may come from charitable source such as zakat and Waqf, the financing must adhere to the strict law of shariah with profit rate-based calculation while conventional financing

\footnotetext{
* Corresponding author: mpisolmatisa@utp.edu.my
} 
solely rely on debt financing with the interest charged over the period of financing tenor. It is vis a vis to banking compounding interest calculation (Abdelkader \& Salem, 2013). The Islamic equity financing based on MFI participation in the business and responsible to business loss incurred, Muhammad Yunus of Grameen Bank stressed on the importance of Microfinance institution (MFI) to work with the spirit and professionalism as other corporate institution however the objective of MFI is different where the prime aim of MFI is not to maximize the profit but helping the poor community (Yunus et al., 2010). However, the success rate is not always happened to every financing transaction. sometime MFI has to face challenging situation due to the customers competency and ability to discharge the business, among them are the low literacy rate, lack of education and attitude problems. Usman \& Tasmin, (2016) found that, low literacy rate and lack of opportunities, the level of education was found to contribute significantly to the economic performance of micro-credit recipients. He also observed that some MFI having difficulty to deal with agency problem, moral hazard and adverse selection process, finally the MFIs including Islamic based microfinance is quite reluctance to offer equity financing due to problem mentioned. Manan \& Shafiai (2015) explored risk management of Islamic microfinance (IMF) product by financial institutions in Malaysia, the study found that MFI industry had experienced a decline in capital inflows, a severe contraction of credit and deterioration of loan portfolio quality that led to the capacity being dried up. The presence of default risk among the borrowers due to the misuse of fund, health condition of the borrowers, and the unfavorable turn-over of business ventures are other sources of risks. Abdul Manap et al. (2017) raised the issue of skills deficiencies and shortages of fund mobilization, and balancing of common pool resources, absence of risk management tools to manage the cases of defaulters, moral hazard, he also pointed out the issue of group lending, where every participant in a group needs to take responsibility of other member in the event of default and failure, this practice has caused trouble and demotivation to some good business entrepreneurs. Fianto et al. (2018) investigated equity and debt-based financing in Islamic microfinance in Indonesia, found that the microentrepreneurs tend to manipulate profit report, this occurred due to lack of participation in the business operation. The study by Mohd Abd Khar et al. (2019) suggested that Islamic equity financing which demands participation from MFI in business should be the best solution for the microentrepreneurs. Her suggestion came out with the notion that the MFI should bear certain amount of risk and take responsibility of any failure of business. In a nutshell her suggestion required MFI to participate in monitoring, coaching and providing technical support to the business. However, this suggestion might not be easy for the MFI to indulge in this form of business due to high probability of business failure. Thus, this study aims to explore the mechanism of risk mitigation which can be adopted by BMT and Islamic microfinance institution in Indonesia and Malaysia. The mechanism would suggest in area of governance, selection of entreprenuer, financing arrangement, payment system and business project.

\section{Literature Review}

\section{Islamic Equity financing}

Abubakar Sadiq Usman \& Tasmin (2016) the role of Islamic micro-finance in enhancing human development in Muslim countries. Low literacy rate and lack of opportunities are among the reasons that made Muslim societies remain in poverty. The level of education was found to contribute significantly to the economic performance of micro-credit recipients. The study also found that the Islamic micro-finance is still lack of capacity in capital and expertise to deal with moral hazards and adverse selection problems. At this stage the study concluded that the practitioners perceived PLS concept is inadequate to support the microfinance business due to exposure to high risk. The current practice in Islamic micro-finance is dominated by micro-credit as against the PLS that enhances venture capital market for long-term growth.

Warninda et al. (2019) investigated the implementation of Mudarabah and Musharakah financing in banking system, especially the impact Islamic Bank on credit risk, her study found Islamic banks around the world still prefer to disburse debt-like or fixed-return financing. while bankers perceive PLS financing potentially generate higher credit risk than fixed return financing. On top of that the PLS financing can cause a principal-agent problem leading to information asymmetry and adverse selection.

There are several studies attempted to discuss Islamic equity financing in microfinance, among them study by Islam (2020) on applicability of Mudarabah and Musharakah as Islamic Micro-equity Finance to underprivileged women in Malaysia, this study focused on woman entrepreneurs preference in term of type of scheme, the study found that women entrepreneurs prefer those Shariah principles that seem easy to comprehend and preserve their interests. This study successfully obtained the views of entrepreneurs on their choice but does not focus on risk issue.

Islamic microfinance and Risk 
Abdul Manap et al. (2017) investigated on the poverty alleviation via microfinance using the concept of mudharabah, the investigation done for the borrower participated in a group lending, the study found that the loan was given in a small loan and on a short-term basis, upon completion of repayment of loans, the new loans may be given based on performance. The model required a social 'guarantee' in which defaulted cases may lead to the whole group be denied of future access to financing. Therefore, the problems such as skill deficiencies, moral hazard and absence of risk management need a serious intention during the selection process. The study ended up with proposal of new model, the model is based on the earlier proposed by Obaidullah (2008) and Kabir \& Salim (2016).

Fianto et al. (2018) assessed the Equity financing and debt-based financing: Evidence from Islamic microfinance institutions in Indonesia, the study reached to the conclusion that despite of the moral hazard associated with the information asymmetry where the entrepreneur could easily manipulate the profit report by reducing the amount of profit in report status. The result shows that clients with equity financing contracts improved their annual income more than clients with debt-based financing. The PLS contracts expose institutions to business risk, however the closed participation of MFI in the business the Islamic MFIs should not act as intermediaries and need to involve in the management of the projects. The model suggested the fund from zakat, waqaf and donation, while the training from CSR program by corporate body, the model also proposed 2 tiers of financing, which the first tier subjected to loss and the successful candidates will be offered for the second tier. This study proved that equity financing with MFI participation may give a different result, however the study didn't focus on risk mitigation of equity financing.

\section{Risk Mitigation in microfinance}

Tamanni (2019) studied on portfolio and default risk of Islamic Microfinance Institutions (IMFs), he explored portfolio and default risk of IMFIs in comparison to conventional microfinance, and the result shown that the Islamic MFIs are facing relatively lower risks than conventional MFIs. This study focuses on general risk with the comparison to conventional MFIs and not on risk mitigation of microfinance. So far not many studies focusing on risk mitigation of Islamic equity financing, however majority of the studies ventured into performance of microfinance and effectiveness of financing and product in catering the poverty problem in society. The study by Mislan Cokro Hadisumarto \& Ismail (2010) on the improving the effectiveness of Islamic micro-financing Learning from BMT experience did mention on the importance of selection process, business control, incentive system, and good relationship in ensuring the effectiveness of micro-enterprises development. The study also investigated the business sectors such agriculture, trading, services, and production. This quantitative research concluded that the potential of Islamic microfinance to improve business income of microentrepreneurs, the study also found that the selection process of ME; business control, incentive system; and good relationship constitute the important factors in achieving the effectiveness of BMT financing. However, this study does focus on strategies taken by MFI in risk mitigation especially on Islamic equity financing.

The most closed study in risk mitigation was taken by Manan \& Shafiai (2015), they investigated risk management of IMFs' product by financial institutions in Malaysia, the study found the Microfinance products are not immune against the risk of financial crisis and credit risk. He also quoted from the literatures, the microfinance industry had experienced a decline in capital inflows, a severe contraction of credit misusing of fund, and other hiccups such as health condition of the borrowers, and also unfavourable turn-over of business ventures are other sources of risks. On the other part this study focuses on product management and the respondence point of view regarding to risk mitigation, the result shown that the institutions had taken measurement to manage risks of micro finance products.

Based on the above literatures show that the current study is important to support the operation of Islamic MFI in discharging its financing fund in effective way. The Islamic MFI needs to have strong ground of governance, the thorough selection process of the suitable microentrepreneur, with support of credit arrangement in term of size of fund and lengthy of tenor, the auto payment system by using the latest technology such as a small device for collection or saving purposes by microentrepreneurs. These operations will finally sustain the business of Microfinance institution. Thus, the current study is important to investigate the mechanism of risk mitigation for equity financing which can be adopted by BMT and Islamic microfinance institution around the world. The mechanism would suggest in the area of governance, selection of entreprenuer, financing arrangement, payment system and business business sectors.

According to Leberman (2015), governance has been one of the most neglected subjects in the microfinance sector. The concern to governance is due to emergence of industry risk such as product risk, operational risk and client risk and the governance also is important to strengthen control and risk oversight. Governance is an action or manner of governing a state, organization, it is originated from the Greek word "kyberman" mean to steer, to guide and govern, the corporate governance defined as the process and structure used to manage business and affair of the company toward promoting business prosperity and corporate accountability. Governance in microfinance should be up to date if not at par with banking institution, as the governance will affect the way of 
MFI is directed. Good governance can sustain MFI for longer period. In Indonesia, BMT supervisory mechanism is regulated by MENEGKOP-UKM decrees. No.35.2/Per/M.KUKM/X/2007 and No.35.3/Per/M.KUM/X/2007. the supervisory and procedures are lies to the official government supervision of the cooperatives. The decrees stipulate a compulsory audit for all BMTs with a total loan portfolio more than IDR 1 billion (Mohamad Nazirwa, 2015), in term of structure and standard of operation, MFIs have different structure and diversified structure and type depending on the sponsorship, some MFI is structured as shareholder-owned institution and some others are government owned companies, majority of BMTs Indonesia which largely practice equity financing are owned by non-governmental institutions such as religious school, university and group of shareholder, as such, governance practiced by them are not exactly as per regulated financial institution. This study will follow the minimum standard drawn by MFIs where the data collection is made. It will cover philosophy of MFI, Standard operation, policies on financing, approval authority,

Selection process is a crucial part of the successful financing, it includes the administrative selection, interview, and feasibility study such as visit and check the business progression. The basic criteria of entrepreneurs include the credibility, honesty, and capability in running business, the other criteria are business experience, collateral and business worthiness. Feasibility study also constitutes an important aspect in selecting microentrepreneur (Mislan Cokro Hadisumarto \& Ismail, 2010).

Type of businesses also play a major part of risk management process, the different business sector may result in different risk, even the same sector may be treated differently as the nature of the business is always required thorough checking and risk assessment, for example trading business may be riskier that agriculture or vice versa, within the service sector such as transportation may be riskier than car workshop or vice versa. The risk mitigation very much depending on the sectors where the risk assessment and strategy should be done properly prior to the deployment of financing. The sectors where MFIs normally involve in financing are trading, services, agriculture, and production (home industries) (Mislan Cokro Hadisumarto \& Ismail, 2010).

Credit control or credit management is another important segment where the MFI will take serious attention especially on the size of funding, credit control on financing performance include credit terms, client appraisal, credit risk control measures and credit collection policies and stage of funding where some financing may be deployed with, in some case MFI will deploy in small amount of funding to their client in order to build up trust and relationship before big financing amount is committed by the MFI. Precautionary measurement onto the new client. E-payment has been seen as a major shift of financial transactional process; the development also brings a new chapter of microfinance payment system. MFIs taking the advantage of the current development. Many scholars embarked research in this area. Donner (2008) jointed the force by investigating mobile payment (mpayment), he found out that the unique criteria of m-payment due to its peculiar characteristics which come along with its usage benefits of cost saving, with the current development of smart phone, almost everyone holds the device, this advantage is massively taken by MFIs. Mwafise \& Stapleton (2012) investigated the user adoption of mobile electronic payment systems for microfinance institutions in Cameroon and found that the majority of microentrepreneurs in Cameroon adopted the technology of m-payment. Mohamad \& Kassim (2019) examined the technology adoption of e-payment adoption among microfinance clients in Malaysia, the analysis reveals that all the variables have no influence on e-payment, researchers further explained that such as result is due to small size of respondents. Development of e-payment in Malaysian MFIs also reach to the matured level by the introduction of its establishment since 2018 when TEKUN launched its mobile application system, TEKUNPay, (Mohamad \& Kassim, 2019). The same initiative was already in use by majority BMT Indonesia, where the collection agent of BMT recording and issuing a receipt immediately after collecting financing from customer in market. (Dumairi, 2020). The device so far plays a major role in term monitoring system to keep track the payment progression of each customer.

The main contribution of this study is to propose a risk mitigation model for islamic equaty-based financing in Islamic microfinance institutions, the proposal will take consideration of the mechenism of risik mitigation in five areas mainly governance approach, selection of entreprenuer, credit management, payment system and business sectors.

\section{METHODOLOGY}

\subsection{Study design}

This study applied qualitative based on interview with practitioner in area of Islamic microfinance, the study is quite unique, since the PLS product so much deals with human character such as trust and respect of both parties (funder and entrepreneur), the respondents are those important industry players which holding highest position in microfinance institution with more than 20 years' experience. We used these methods as the informants can reveal information and ways on how the operation and process of risk mitigation procedures was taken place in the individual MFIs, the respondents also provided solution to some critical issues and problems especially in the event of default and prior to default. The five BMTs in Indonesia are among the most successful microfinance 
institutions and involve with financing amount more than USD one million total financing in a year. The interviews were conducted during January 2020 and Mac 2020 at the MFIs office in Indonesia.

\subsection{Recruitment}

The study consists of 5 respondents of the chosen Indonesian BMT. The respondents were selected based on previous research. the BMT practitioners were invited is due to the success story of equity-based financing application in Indonesia. The respondents were contacted through a contact person who are also involved in BMT in East Jawa Indonesia, some of the respondents were in frequently contacted with researcher, and some others were selected from co-researchers who are also active in Islamic finance research. The respondents are the key person in the institutions, well understanding of Islamic theoretical concept of Islamic financial product, holding high position and they are among the top management team in the institutions.

\subsection{Sampling strategy}

Sampling strategy applied theoretical sampling where some literature and previous research has informed to the respondents' organization, in order to have more sampling the study also applied snowball sampling by getting the information of the rest of other respondents from the first respondent. This study is very specialized and very focus on risk mitigation model, it needed an intensive study, therefore the study only collecting data from small respondents who has vast experience and expertise in Islamic microfinance industry. our analysis revealed that more than $80 \%$ of themes were discoverable and the respondents interviewed were enough to identify most of the prevalent themes within the data set.

\subsection{Data collection}

The study used semi-structured interview, the questionnaire is designed prior to the interview and it based on the research objective and guided with literature review especially the component of financing criteria which triggered risk exposure of microfinancing. The interviews were conducted at the MFIs premises, the interviewers were led by research principal investigator (PI), the interviews were taken place around two hours' time. All data were recorded with two recording hand phones, this is to ensure the data collected secured and will not be missing in the case of any device is going to disfunction.

\subsection{Data analysis}

This study will use the open coding, by applying the inductive concept of data-driven analysis the author will identify and categorize the phenomena by creating a proper theme deriving from the codes.

\section{Discussion}

There are mechanisms used to mitigate the risk in five areas mainly governance, selection of entreprenuer, credit management, payment system and business sectors. This part of paper is very crucial to obtain the MFIs strategies in mitigating their risk while managing equity financing.

\subsection{Governance approach}

Since the governance of MFIs is diversified in term of structure and type depending on the sponsored institutions, some MFI is structured as shareholder-owned institution and some others are government owned companies (Nazirwan, 2015), therefore the governance on risk mitigation applied by the BMTs are not all the same.

The approach of governance in risk mitigation normally focusing on the internal process of BMT in managing their resources and operations with its objective to enhance their business's efficiency. Majority of BMTs applying dakwah concept as a tool to create atmosphere of Islamic environment especially in business transaction, dakwah is a religious call to God-fearing and God-consciousness, which emphasizes on two parts, educating client on implementation of Syariah and its benefit specifically in financing environment, and developing trustworthiness among client and BMT to develop credibility and transparency in the business process and transaction. According to BMT 1,

The first and foremost is about changing the people mindset, it must be done with familiarizing the people with Shariah financial services, since majority of people mindset are conventional orientated, the effort to instil Islamic knowledge by applying basic Islamic terminology in business transaction could be one of the small starts of the process. 
BMT2 echoes the same tone by saying that.

By having a constant visit and dakwah, both BMT staff and client would automatically be fostering a strong silaturrahim (good friendship), as a result of this relationship, the participants will easily disclose the real business account to BMT staff, on top of that BMTs ready to reduce its profit portion whenever the business recorded high return.

Similar approach also applied by BMT 3, where the emphasis on executing transaction based on Syariah not only to their client but also to the surrounding community. Topics on the prohibition of interest-bearing system is taught and discussed with the objective to create awareness and perhaps to avoid such transaction in community. dakwah also posted as a mean to deepen the bond between clients and BMT. Majority of BMTs are aware the need to have solid bond to make sure their clients are honest to BMT, hence any business progress and related business issues to be shared with BMT staff. In order to fulfil this important objective, BMTs apply different approaches of dakwah. BMT 2, conducting frequent social activities that involves clients and BMT staff through monthly gathering and home visit. While BMT 5, conducting training to improve clients' business skill, which will directly improve the capability in handling their business. The elements of dakwah always play a major part in this activity. As a result of this approaches, the relationship between BMT and business clients are strongly bonded, and any shortcoming and problem could be easily resolved in a friendly manner. Risk mitigation strategy through dakwah approach is workable for BMTs in Indonesia evidenced by the minimum NPF below $2 \%$ annually. Bear in mind that, majority of BMTs are not applying late payment charge (LPC) for its client.

Technology plays a vital role in facilitating BMT in managing their operations and mitigating its business risk. Majority of BMTs are utilizing IT facilities in business operation, which include to facilitate the repayment collection and monitoring of clients' business progress. Majority of BMTs (1,2,3 and 4) applied IT facility to monitor client repayment, while BMT 5 still using conventional method of collection due to the majority of its clients stay at the remote location and client's comfortability, BMT 1 has developed its owned mobile application which can be downloaded from "google play store", where the App is able to control the movement of clients" account, the usage of app has increased its control and monitoring system which ultimately be able to mitigate the risk of NPF at early stage, however the approach of face to face still relevant especially to those clients who face difficulty in financing repayment. BMT1 states that,

Our BMT monitor the repayment of financing in two ways, the first approach is done through integrated online system, our collection staff will visit the clients, weekly or monthly according to the nature of business, in the event of failure, the second approach is taken by the standard operation where BMT's staff will approach the client for further discussion.

Although those BMTs have started to apply technology, manual works are still in use especially in monitoring client in rural area and gave low technology literacy. The BMTs are aware on the importance in applying technology in this current digital age. Although they only focus on specific area currently, technology functions as business support, it can be utilized to the whole institution. This align with the literature that to make sure these BMT to continue playing their role in serving poor people in long run, microfinance institution needs to start familiarizing and embracing new technologies and adapt it in their business models (Mohamad \& Kassim, 2019).

Limit authority in approving the financing amount posits as one of the important components in risk mitigation. Limit authority of BMT management in deciding any decision relating to eligible client, business sector and size of financing. Management staff at all levels should have strong capability in analyzing those criteria before endorsing the financing to eligible clients. BMT 1 and 2 include their staff in business at early stage of contract is assigned in order to consult and trace business performance. In the case of BMT 5, the BMT has taken long process, where all applications have to get the final approval from central committee, and written recommendation from relevant parties are needed.

Islamic Insurance or Takaful play as the last gate of risk mitigation. The purpose of the Takaful is to protect the clients form any unwanted event, majority of BMTs demand clients to apply for Islamic insurance in the case of death and other calamity. In the case of BMT4, the financing of more than 50 mil rupiah is compulsory to apply for Islamic insurance. BMT 2 has not directed the takaful as the compulsory condition but always demand the clients to require it as a mechanism of repayment in the case of death.

Company evaluation and monitoring is one of the important elements in governance. All BMTs agreed that they need to continuously monitor their client performance in handling the business. BMT 3 said that the monitoring process will help in identifying possible factors that may lead to business failure, thus giving them early steps to execute necessary action. Meanwhile, BMT 1, 4 and 5 emphasizes that monitoring is necessary to make sure the clients are managing their businesses, monitoring their sales and cashflow, and adhere to the contract that requires transparency and credible information from client. 


\subsection{Selection}

Every BMT have similar selection criteria for their potential client. Majority of BMTs state the preference to the experienced client with at least three years of business activity in the area concerned, but still open to newcomer. This can be seen at BMT1, BMT2 and BMT3 that require client to have at least three years of experience with the BMT before discharging the equity fund, in contrary to BMT4 which targeting on new clients the to offer equity financing as compared to debt financing, the new contract of Mudarabah and Musyarakah (M\&M) offered in BMT4 are dominated by new clients, meanwhile the experienced client prefers Murabahah contract. For BMT2 and BMT3 clearly highlighted the important condition that the client to undergo Murabahah contract first to testify the eligibility before receiving M\&M contract. Checking upon client is a part of the evaluation process to the potential client. Majority of BMTs include the process in their list of required condition. BMT1 applied neighbor checking strategy by sending an officer to the potential client area, the interview session with the head of village and Imam of the mosque pertaining to potential client. BMT2 add in the checking process upon client with the information from other financial institutions if any. Meanwhile, BMT 5 solicits the information on the business consist of current work, fund requirement, repayment ability and business security. BMT3 added ceiling of financial provision, the amount of ceiling is based on client financial needs and analysis done by the officer as their selection criteria. Qualitative criteria is another important criterion as the standards sets to understand customer behavior indirectly. BMT3 uses qualitative criteria to understand customer motive and intention in subscribing the M\&M. BMT 5 states that qualitative criteria used in selecting client derived from two sources which are from client themselves when they approach BMT and suggestion from the officer. Selecting right client is a high priority in determining the potential business success which will greatly affect the institution sustainability (Mislan Cokro Hadisumarto \& Ismail, 2010). Credit evaluation is evaluating the client credit status prior to receiving the fund. BMTs state that the criteria focusing on the client's capital and collateral. BMT5 will conduct financing analysis to evaluate client's overall potential based on intention, willing to pay and capability to pay.

\subsection{Payment System}

Usage of online payment as technological support to enhance the payment process. For BMT1, payment is done through dedicated central system. This system will synchronize with the central office that help in maintaining credible data. BMT3 has already embarked the usage of mobile application that offer the client to use it for any payment, getting latest info and raise any issues. The usage of technology does not only help in maintaining credible data but also reduce processing time and help to connect every client at any places. This results is aligned with study from Mwafise \& Stapleton (2012). Although both BMTs have utilized technology, manual works are still available for those who do not have accessibility to use it, for example rural community or elderly people. BMT2 applies compulsory saving for its client as the method to make sure client have the capability to pay back. Clients need to deposit into their saving account a portion of their daily profit. The savings are taken from sales profit and been used for instalment fee.

\subsection{Business Sector}

The selected businesses to venture are carefully selected by BMT based on the needs of the people. According to BMT 1, the distribution of fund and the business to pursue should follow the needs of the industry and community. This will allow the opportunity to educate the community on related Fiqh and Syariah to increase their awareness on the Fiqh Muamalah. Mudharabah muqayyadah (sharing contract for a certain product) is one of the methods used by the BMT for their client. This type of contract normally been used for new client with no experience in business and business with high turnover trading items as explained by BMT2. BMT3 justified that this contract is used for certain commodity trading items as the measure in minimizing the risk, by applying mudharabah muqayyadah especially with new client without prior experience in handling the business, it helps the institution to prepare the appropriate capital and ready to venture in the risky business activities. Based on the data collected all five BMTs choose to venture in trading sector. Following next are construction and textiles with three BMTs venture in it, other two BMTs venturing in agriculture and fishery, and only one BMT venture in home industry, food production, manufacture, and printing.

\subsection{Credit Management}

Credit management is a mechanism of credit control on financing performance including credit terms, client appraisal, credit risk control measurement and credit collection policies. The steps taken by BMTs while dealing with the default case, the BMTs will take the steps such as rescheduling, restructuring, and reconditioning. Majority of BMTs in Indonesia will take similar steps, some of BMTs added other items for their process. Such 
as BMT4, The BMT requires a payment rescheduling by increasing outstanding and write off. BMT2 highlights the requirement of saving to the client as the condition to avoid this issue. Managing the risk of NPF is crucial in maintaining the cashflow of the microfinance institution (Warninda et al., 2019). Contract is one of the necessary components in M\&M that holds between BMT and its client. All BMTs agreed that the contracts depend on the nature of the business. BMT3 specifically states that the different business will have different terms and condition Meanwhile, BMT4 stated that the motive of this contract is to safeguard the interest of the BMT, client and all related stakeholders.

The financing amount which in practice by BMTs is depending on the agreement between BMTs and Clients. Majority of the BMTs provide the financing amount between USD 35 to USD 14,000. The tenor of repayment is between 3 months to 3 years depending on the nature of business and the risk assessment by the officer. The highrisk business will be the shorter tenor and vice versa. all BMTs require collateral for the client. Majority required physical items such as house and land. The Repayment of financing is normally made based on the nature of the business, some repayment is weekly and some other is periodically depending on project completion. The repayment is subjected to the agreement between BMTs and clients.

\section{Conclusion}

The potential of risk in microfinance institution is unavoidable especially when dealing with social business and lower income earner, this is due to financial literacy, attitude, knowledge, and ability to manage the business fund. Islamic MFI should implement various risk mitigation methods in maintaining the sustainable development of microfinance institution such as BMT. The risk mitigation methods that had been applied at several BMT in Indonesia into several areas such as governance, selection, payment systems, business sector and credit management. The study found that, there are several common actions among all Islamic MFIs which has been implemented in mitigating the risk such as managing human capital though dakwah concept by highlighting God consciousness and God fearing, usage of ICT facility as the support tools, selecting the right candidate in managing the fund, effort in reducing the volume of NPF and continues monitoring the client. However, there are few steps that are unique such as the implementation of takaful or microinsurance upon the client, type of industries to venture and the usage of mudharabah muqayyadah in finalizing the contract between client and microfinance institution is also part of the risk mitigation.

\section{References}

Abdelkader, I. Ben, \& Salem, A. Ben. (2013). Islamic vs Conventional Microfinance Institutions: Performance analysis in MENA countries. International Journal of Business and Social Research, 3(5), 218-233. https://doi.org/10.18533/ijbsr.v3i5.21

Abdul Manap, S. H., Siththi, F., Long, S., \& Muneeza, A. (2017). Poverty Alleviation via Microfinance using the Concept of Mudharabah. International Journal Of Management and Applied Research, 4(3), 166-178. https://doi.org/10.18646/2056.43.17-013

Abdul Rahman, A. R. (2007). Islamic Microfinance: A Missing Component in Islamic Banking. Kyoto Bulletion of Islamic Area Studies, 2-3.

Donner, J. (2008). Research approaches to mobile use in the developing world: A review of the literature. Information Society, 24(3), 140-159. https://doi.org/10.1080/01972240802019970

Fianto, B. A., Gan, C., Hu, B., \& Roudaki, J. (2018). Equity financing and debt-based financing: Evidence from Islamic microfinance institutions in Indonesia. Pacific Basin Finance Journal, 52(September 2017), $163-172$. https://doi.org/10.1016/j.pacfin.2017.09.010

Islam, R. (2020). Applicability of Mudarabah and Musharakah as Islamic Micro-Equity Finance to the Underprivileged Women in Malaysia. The European Journal of Development Research.

Juwaini, A., \& Mintarti, N. (2010). BMT ( Baitulmaal wa Tamwil ) Islamic Micro Financial Services For The Poor. ISO/Copolco Workshop Bali, 1-15.

Kabir, S., \& Salim, R. (2016). Two-staged Capital Structure : An Operational Guideline for Islamic Microfinance System. Jel, 05/16. https://doi.org/10.13140/RG.2.1.3686.3768

Manan, S. K. A., \& Shafiai, M. H. B. M. (2015). Risk Management of Islamic Microfinance (IMF) Product by Financial Institutions in Malaysia. Procedia Economics and Finance, 31(15), 83-90.

https://doi.org/10.1016/s2212-5671(15)01134-x

Mislan Cokro Hadisumarto, W., \& Ismail, A. G. (2010). Improving the effectiveness of Islamic microfinancing: Learning from BMT experience. Humanomics, 26(1), 65-75. 
https://doi.org/10.1108/08288661011025002

Mohamad, S. A., \& Kassim, S. (2019). Examining the Relationship between UTAUT Construct, Technology Awareness, Financial Cost and E-Payment Adoption among Microfinance Clients in Malaysia. 292, 351-357. https://doi.org/10.2991/agc-18.2019.56

Mohd Abd Khar, S. H., Mohd Mat Isa, M. P., Marimuthu, M., \& Jan, A. (2019). The Perception of MicroEntrepreneurs towards the Adoption of an Islamic Equity-Based Financing: Evidence from Malaysia. Business Management and Strategy, 10(2), 97. https://doi.org/10.5296/bms.v10i2.15586

Mwafise, A. M., \& Stapleton, L. (2012). Determinants of user adoption of mobile electronic payment systems for microfinance institutions in developing countries: Case study cameroon. In IFAC Proceedings Volumes (IFAC-PapersOnline) (Vol. 45, Issue 10). IFAC. https://doi.org/10.3182/20120611-3-IE-4029.00010

Nazirwan, M. (2015). The Dynamic Role and Performance of Baitul Maal Wat Tamwil : Islamic CommunityBased Microfinance in Central Java.

Obaidullah, M. (2008). Introduction to Microfinance. In IBF Net (P) Limited.

Tamanni, L. (2019). Portfolio and Default Risk of Islamic Microfinance Institutions. 8, 056-075.

Usman, A.S, \& Tasmin, R. (2016). Linkage Between Islamic Micro-Finance and Poverty Reduction in Malaysia. International Business Management, 10(17), 3739-3746.

Usman, Abubakar Sadiq, \& Tasmin, R. (2016). The Role of Islamic Micro-Finance in Enhancing Human Development in Muslim Countries. Journal of Islamic Finance, 5(1), 53-62. https://doi.org/10.12816/0027652

Warninda, T. D., Ekaputra, I. A., \& Rokhim, R. (2019). Do Mudarabah and Musharakah financing impact Islamic Bank credit risk differently? Research in International Business and Finance, 49(September 2017), 166-175. https://doi.org/10.1016/j.ribaf.2019.03.002

Yunus, M., Moingeon, B., \& Lehmann-Ortega, L. (2010). Building social business models: Lessons from the grameen experience. Long Range Planning, 43(2-3), 308-325. https://doi.org/10.1016/j.lrp.2009.12.005 